\title{
Optimization of durability properties of concrete containing fly ash using Taguchi's approach and Anova analysis
}

\section{Optimización de las propiedades de durabilidad del hormigón que contiene ceniza, utilizando el enfoque Taguchi y análisis Anova}

\section{Mucteba Uysal}

Istanbul University-Cerrahpasa, Faculty of Civil Engineering

34320, Avcilar Campus, Avcilar, Istanbul, Turkey

mucteba.uysal@istanbul.edu.tr

\section{Veysel Akyuncu}

Namik Kemal University, Engineering Faculty, Civil Engineering Department 59860, Corlu Campus, Tekirdag (Turkey)

vakyuncu@nku.edu.tr

\section{Harun Tanyildizi}

Firat University, Technology Faculty, Department of Civil Engineering

23119, Elazig (Turkey)

htanyildizi@firat.edu.tr

\section{Mansur Sumer}

Sakarya University, Engineering Faculty, Civil Engineering Department 54187, Esentepe Campus, Sakarya (Turkey)

msumer@sakarya.edu.tr

\section{Hasan Yildirim}

Istanbul Technical University, Faculty of Civil Engineering, 34469, Ayazaga Campus, Istanbul (Turkey)

hasanyildirim@itu.edu.tr

Manuscript Code: 987

Date of Acceptance/Reception: 03.12.2018/05.10.2017

DOI: 10.7764/RDLC.17.3.364

\begin{abstract}
In this study, optimization of durability properties of the concretes was performed by using Taguchi method and Anova analysis. The durability performance of the concretes was evaluated using measurements of rapid chloride ion permeability, freezing-thawing resistance and sorptivity tests. The degree of freezing-thawing resistance was assessed the change of weight, ultrasonic pulse velocity (UPV) and flexural strength after 300 cycles. The use of fly ash improved the rapid chloride ion permeability and sorptivity of concrete. The best resistance to chloride ion permeability was obtained from a combination of type of class C fly ash content of $102 \mathrm{~kg} / \mathrm{m}^{3}$ with PC content of $332 \mathrm{~kg} / \mathrm{m}^{3}$. There was a remarkable reduction in the UPV after the specimens are subjected to freezing-thawing cycles. The amounts of flexural strength loss have been measured in the range of $6.70-29.83 \%$. The use of type of class C fly ash positively affected freezing-thawing resistance of concrete. The Anova analysis indicated that the cement dosage has an utmost importance on the sorptivity level, chloride ion permeability and ultrasonic pulse velocity loss. Furthermore, the fly ash percentage has an utmost importance on the weight loss and flexural strength loss.
\end{abstract}

Keywords: Type of class C fly ash, sorptivity, Chloride ion permeability, freezing-thawing resistance.

Resumen

En este estudio, la optimización de la durabilidad de las propiedades de los hormigones se realizó utilizando el método Taguchi y análisis Anova. El rendimiento de la durabilidad de los hormigones fue evaluado utilizando medidas de permeabilidad rápida a los iones de cloruro, pruebas de resistencia a la congelación-descongelación y de capacidad de absorción de agua por capilaridad. En el grado de resistencia a la congelacióndescongelación se evaluó el cambio de peso, la velocidad del pulso ultrasónico (UPV) y la resistencia a la flexión después de 300 ciclos. El uso de la ceniza mejoró la rápida permeabilidad de los iones de cloruro y la capacidad de absorción de agua por capilaridad del hormigón. La mejor resistencia a la permeabilidad del ion de cloruro fue obtenida de una combinación de tipo de ceniza clase C de $102 \mathrm{~kg} / \mathrm{m}^{3} \mathrm{con}$ un contenido de PC de $332 \mathrm{~kg} / \mathrm{m}^{3}$. Hubo una notable reducción en la UPV después de que las muestras se sometieran a ciclos de congelación y descongelación. Las cantidades de fuerza flexible perdidas han sido medidas en el rango de 6.70 a $29.83 \%$. El uso del tipo de ceniza clase C afectó positivamente a la resistencia de la congelación y descongelación del concreto. El análisis de Anova indicó que la dosis de cemento tiene una importancia mayor sobre el nivel de la capacidad de absorción de agua por capilaridad, la permeabilidad del ion de cloruro y la pérdida de velocidad del pulso ultrasónico. Además, el porcentaje de ceniza tiene una importancia mayor en la pérdida de peso y en la pérdida de la fuerza flexible. 
Concrete is a material that the most widely utilized man-made product in the world, and is second only to water as the world's most used substance. More than a ton of concrete is produced slightly each year for every human being on the planet, some six billion tons a year. Concrete is a reliable and affordable material that is applied throughout the infrastructure of a nation's construction, transportation, industrial, defense, utility and residential sectors (Siddique, Aggarwal, Aggarwal, Kadri, \& Bennacer, 2011). Recently, since durability is one of the critical issues to construct reinforced concrete structures with long service life and develop construction technologies due to some environmental and economic reasons, it is important to produce well-designed concrete as a durable construction material (Bilim, Atis, Tanyildizi, \& Karahan, 2009). However, large amounts of cement are used in concrete production. Cement is one of the most cost- and energy-intensive component of concrete. Three billion tons of raw materials are used in each year for cement production (Yuksel, Bilir, \& Ozkan, 2007) and cement manufacturing is responsible for about $2.5 \%$ of total worldwide $\mathrm{CO}_{2}$ emissions from industrial sources in the world (Cakir \& Akoz, 2008; Aldea, 2000). In modern concrete construction, the use of additional cementitious materials due to economic, technical and environmental considerations has become very common. The use of these materials in concrete is increasing because they result in lower cost of construction and improve some mechanical, physical and durability properties of concrete in aggressive environments (Chung, Shon, \& Kim, 2010). Mineral admixtures such as ground granulated blast furnace slag, silica fume and fly ash (FA) generally improve the engineering properties of concrete when they are used as a mineral admixture or partial replacement of cement (Mohammed \& Fang, 2011; Li \& Zhao, 2003). Among these mineral admixtures, FA has been used in concrete production for over 56 years in the world. It was used in mass conventional and high strength concrete to improve the workability to reduce the heat of hydration and thermal cracking at early ages and to improve the technical, mechanical and durability properties especially at later ages (Sahmaran \& Li, 2009). The main useful effect of FA in concrete consists of three aspects, often called pozzolanic effect, morphologic effect and micro aggregate effect. The pozzolanic effect is the main effect of FA, which states that the unfixed $\mathrm{Al}_{2} \mathrm{O}_{3}$ and $\mathrm{SiO}_{2}$ in $\mathrm{FA}$ can be activated by $\mathrm{Ca}(\mathrm{OH})_{2}$ product of cement hydration and it is produced more hydrated gel by this effect (Cao, Sun, \& Qin, 2000). Since the gel produced from pozzolanic action can fill in the capillary in concrete, it effectively contributes to concrete strength. The micro aggregate effect of FA states the microbeads in FA can disperse well in concrete and combine firmly with gel produced in cement hydration, and thus conduce concrete density (Cao et al., 2000). The morphologic effect indicates that there are many microbeads in FA working as "lubricating balls" when incorporated in fresh concrete; hence it benefits the fluidity (Cao et al., 2000).

Fly ash is commonly used in blended cements, and is a by-product of coal-fired electric power plants (Alonso \& Wesche, 1992). Two general classes of fly ash can be defined: low-calcium fly ash (ASTM Class F) produced by burning bituminous or anthracite coal; and high-calcium fly ash (ASTM Class C) produced by burning lignite or sub-bituminous coal (Nochaiya, Wongkeo, \& Chaipanich, 2010). Class F is categorized as a normal pozzolan, a material consisting of silicate glass, modified with iron and aluminum. Type of class $\mathrm{F}$ requires $\mathrm{Ca}(\mathrm{OH})_{2}$ to form strength-developing products (pozzolanic reactivity), and therefore is used in combination with Portland cement, which produces $\mathrm{Ca}(\mathrm{OH})_{2} \mathrm{during}$ its hydration. It lowers the heat of hydration and improves the durability properties of concrete when used in concrete as a cement replacement. It also conduces to concrete strength by pozzolanic and filler effects (Papadakis, 1999). The current worldwide production of coal ash is estimated about 700 million tones per year of which at least $70 \%$ is fly ash. There are 19 thermal power plants actively working in Turkey but type of class $\mathrm{F}$ fly ash is obtained only from Catalagzi Thermal Power Plant, FA of all other plants is type of class C. The annual fly ash production is about 20 million tones which is more than the rest of all industrial wastes in Turkey. Although FA is a valuable mineral additive for blended Portland cement and concrete, only about $4 \%$ of the total available FA is used for this purpose in Turkey (Yazici, Aydin, Yigiter, \& Baradan, 2005). Particularly, due to the energy demand, the production rate of FA is expected to increase in the future (Felekoglu, 2006).

In severe environments, durability is a key function for materials which are used (Soroushia, Nagi, \& Okwuegbu, 1992; Alexander \& Magee, 1999). The freezing and thawing durability is especially important for a porous brittle material such as concrete when it is subjected to lower temperatures in cold environments (Cai \& Liu, 1998). Frost damage, a progressive deterioration is a major concern when concrete is used in colder regions which starts from scaling or surface separation and ends up with complete collapse. The deterioration proceeds as freezing-thawing cycles are repeated, and the material gradually loses its strength and stiffness. In addition, increasing irreversible expansion is stimulated. So, the freezing and thawing action could be looked upon as one of the complex fatigue process. Now, there are increasing needs for concrete to be used for the lack of very cold substances. So, it is essential a rational 
evaluation of deterioration is in designing more reliable structures and minimizing possible damage (Shang, Song, \& Qin, 2008).

The use of Taguchi and Anova methods in concrete technology has become widespread in recent years to optimize properties of concrete (Tanyildizi, \& Sahin, 2015; Mohebi, Behfarnia, \& Shojaei, 2015; Tanyildizi, 2018, Jafari, Tabatabaeian, Joshaghani, \& Ozbakkaloglu, 2018; Tanyildizi, 2013; Tanyildizi et al., 2008; Tanyildizi, 2014). Tanyildizi and Sahin (Tanyildizi \& Sahin, 2015) applied Taguchi method for optimization of concrete strengthened with polymer after high temperature. They reported that Taguchi analysis indicated the optimum parameters for ultrasonic pulse velocity and the compressive strength of concrete. Also, Anova analysis showed that the most effective parameters on the compressive strength and ultrasonic pulse velocity of concrete. Mohebi et al investigated abrasion resistance of alkali-activated slag concrete designed by Taguchi method and they declared that Taguchi method could be an effective and suitable design of experiment method for optimizing alkali-activated slag concrete parameters to achieve the maximum compressive strength and abrasion resistance (Mohebi et al., 2015). Tanyildizi also investigated long-term microstructure and mechanical properties of polymer-phosphazene concrete exposed to freeze-thaw. The effects on experimental results of each factor were determined using Anova. The results obtained using Anova analysis showed that cement dosage had made the most effective parameter (Tanyildizi, 2018). Jafari et al. (2018) used Taguchi and Anova methods to optimize the mixture design of polymer concrete. They reported that the optimum mix design of polymer concrete was determined using Taguchi and Anova methods.

The objective of this study is to investigate the effect of the use of type of class C fly ash as partial replacement of cement in various percentages on concrete properties. Several properties related to durability were determined such as chloride ion permeability resistance, sorptivity and particular attention was put on the resistance of the concrete mixes to the freezing and thawing cycles based on ASTM C 666. Taguchi method and Anova analysis were used to optimize durability properties of the concretes containing type of class $\mathrm{C}$ fly ash.

Methodology

\section{Materials}

In this study, CEM I 42.5 R Portland cement and type of class C fly ash were used as binding materials. Their chemical compositions and properties are shown in Table 1. Type of class C fly ash was obtained from power plants in Turkey. Specific gravity of the cement used was $3.12 \mathrm{~g} / \mathrm{cm}^{3}$. Initial and final setting times of the cement were 210 and $265 \mathrm{~min}$, respectively. Crushed limestone aggregates with a maximum size of $16 \mathrm{~mm}$ were used as coarse aggregates. The specific gravity and water absorption of the crushed limestone aggregate was 2.70 and $0.31 \%$ respectively. Ordinary river sand with specific gravity of 2.61 and water absorption of $1.59 \%$ was also employed. A uniform grading of aggregate mixture was prepared. The fineness modulus of the mixture is 4.09 . Volume percentages of aggregates were kept constant in all mixtures which means that aggregate quantities changed for each series but volume percentages of aggregates were kept constant for all aggregates in each series.

\begin{tabular}{|c|c|c|}
\hline \multicolumn{3}{|c|}{ Chemical composition } \\
\hline Component & Cement (\%) & Class C fly ash (\%) \\
\hline $\mathrm{SiO}_{2}$ & 20.63 & 46.38 \\
\hline $\mathrm{Fe}_{2} \mathrm{O}_{3}$ & 3.41 & 8.26 \\
\hline $\mathrm{Al}_{2} \mathrm{O}_{3}$ & 4.71 & 13.9 \\
\hline $\mathrm{CaO}$ & 63.64 & 15.1 \\
\hline $\mathrm{MgO}$ & 1.24 & 6.68 \\
\hline $\mathrm{SO}_{3}$ & 2.98 & 4.26 \\
\hline Loss Ignition & 1.25 & 0.22 \\
\hline $\mathrm{K}_{2} \mathrm{O}$ & 0.91 & 2.78 \\
\hline $\mathrm{Na}_{2} \mathrm{O}$ & 0.23 & 2.13 \\
\hline Free $\mathrm{CaO}$ & 1.1 & 0.15 \\
\hline \multicolumn{3}{|c|}{ Physical properties } \\
\hline Specific & 3.12 & 1.84 \\
\hline \multicolumn{3}{|l|}{ Gravity (\%) } \\
\hline Blaine $\left(\mathrm{cm}^{2} / \mathrm{g}\right)$ & 3545 & 2850 \\
\hline
\end{tabular}


Three different cement dosages $\left(260,320,400 \mathrm{~kg} / \mathrm{m}^{3}\right)$ and two various replacement ratios of cement from the reference concretes were used in this study. The workability values of mixtures were similar to each other with a slump of $145-175 \mathrm{~mm}$. The main variable in the mixtures was the water content, the cement and fly ash. The mixture proportions of the concretes are shown in Table 2. The raw materials of concrete were put in a forced mixer at the same time and were mixed for 3 - 4 minutes. The mixtures were cast into test specimens in mould by vibration. 6 series of concretes containing type of class $\mathrm{C}$ fly ash and 3 series of reference mixtures were produced in order to investigate durability properties of concretes.

\begin{tabular}{lcccccccc}
\multicolumn{10}{c}{ Table 2. Mixture proportion of concretes. Source: Own elaboration. } \\
\hline Concrete Type & $\begin{array}{c}\text { Cement } \\
\left(\mathrm{kg} / \mathrm{m}^{3}\right)\end{array}$ & $\begin{array}{c}\text { Fly Ash } \\
\left(\mathrm{kg} / \mathrm{m}^{3}\right)\end{array}$ & $\begin{array}{c}\text { Sand } \\
\left(\mathrm{kg} / \mathrm{m}^{3}\right)\end{array}$ & $\begin{array}{c}\text { Type I Agg } \\
\left(\mathrm{kg} / \mathrm{m}^{3}\right)\end{array}$ & $\begin{array}{c}\text { Type II Agg } \\
\left(\mathrm{kg} / \mathrm{m}^{3}\right)\end{array}$ & $\begin{array}{c}\text { Water } \\
\left(\mathrm{kg} / \mathrm{m}^{3}\right)\end{array}$ & $\begin{array}{c}\text { w/b } \\
\text { ratio }\end{array}$ & $\begin{array}{c}\text { Slump } \\
(\mathrm{mm})\end{array}$ \\
\hline C260 & 260 & - & 765 & 806 & 346 & 179 & 0.68 & 175 \\
C234C26 & 234 & 26 & 771 & 811 & 348 & 180 & 0.69 & 168 \\
C216C66 & 216 & 66 & 761 & 813 & 342 & 188 & 0.66 & 160 \\
C320 & 320 & - & 742 & 779 & 334 & 205 & 0.64 & 153 \\
C288C32 & 288 & 32 & 740 & 775 & 330 & 194 & 0.60 & 155 \\
C266C54 & 266 & 54 & 743 & 786 & 345 & 185 & 0.58 & 162 \\
C400 & 400 & - & 716 & 762 & 328 & 172 & 0.43 & 145 \\
C360C60 & 360 & 60 & 721 & 768 & 321 & 175 & 0.42 & 148 \\
C332C102 & 332 & 102 & 715 & 770 & 350 & 174 & 0.40 & 165 \\
\hline
\end{tabular}

\section{Casting, testing and curing of specimens}

All specimens were demoulded in a controlled chamber at $23 \pm 1{ }^{\circ} \mathrm{C}$ after $1 \mathrm{~d}$ of casting and cured at $20{ }^{\circ} \mathrm{C}$ and $65 \% \mathrm{RH}$ in lime-saturated water. Specimens of concrete with dimensions $70 \times 70 \times 280 \mathrm{~mm}$ were used for freezing-thawing resistance tests. For all results, the average of experimental results from three identical specimens was adopted. After 1 day of moist curing, specimens from each mixture were cured in lime-saturated water at $23 \pm 1{ }^{\circ} \mathrm{C}$ until $28 \mathrm{~d}$. Then, they were exposed to 300 cycles frozen in "deep-freeze" at $-18 \pm 1{ }^{\circ} \mathrm{C}$ and thawed in water at $4 \pm 1{ }^{\circ} \mathrm{C}$ (for each cycle they were kept in deep-freeze and water for $4 \mathrm{~h}$ ). Freezing and thawing test was done according to the ASTM C 666 procedure B (ASTM C666, 2008). The resistance to freezing and thawing cycling was determined on test prisms; the changes in mass, ultrasonic pulse velocity of the three prisms by measuring the ultrasonic pulse velocity and weight variation were determined after 300 cycles. The flexural strength of the test prisms was also determined after the completion of the test and compared with that of the reference prisms cured in the tap water.

The velocity of the propagation of ultrasound pulses was measured according to ASTM C 597 (ASTM C597-02, 2002) by direct transmission using a Controls E48 ultrasound device. This device measures the time of propagation of ultrasound pulses in a sample in the range (0.1-9999.9) $\mu$ s with a precision of $0.1 \mu \mathrm{s}$. The transducers used were 50 $\mathrm{mm}$ in diameter, and had maximum resonant frequencies, as measured in our laboratory, of $54 \mathrm{kHz}$.

The deterioration of the concrete specimens was investigated by determining the flexural strength loss, which was calculated as follows.

$$
\text { Flexural strength loss }(\%)=[(A-B) / A] \times 100
$$

where, $A$ is the average flexural strength of concrete specimens cured in tap water (MPa) and $B$ is the average flexural strength of concrete specimens immersed in test solution (MPa) for the same period.

The cylinders (100 mm x $200 \mathrm{~mm}$ ) were cast for rapid chloride penetration resistance test and were sliced $51 \mathrm{~mm}$ thick of $102 \mathrm{~mm}$ nominal diameter. Rapid chloride penetration resistance test (according to ASTM C 1202-97) covered the determination of the electrical conductance of concrete to provide a rapid indication of its resistance to the penetration of chloride ions (ASTM C1202, 1994). The test method consisted of monitoring the amount of electrical current passed through $51 \mathrm{~mm}$ thick slices of $102 \mathrm{~mm}$ nominal diameter cores or cylinders for a $6 \mathrm{~h}$ period. A potential difference of $60 \mathrm{~V}$ DC was maintained across the ends of the specimen, one of which was immersed in a sodium 
chloride solution, the other in a sodium hydroxide solution. The total charge passed, in coulombs, was related to the resistance of the specimen to chloride ion penetration.

The sorptivity test was based on ASTM C1585 (ASTM C1585, 2004). The test consisted of registering the increase in mass of a cubic specimen when permitted to absorb water by capillary suction at given intervals of time. In this test method, the cumulative volume of water absorbed per unit surface area $\left(\mathrm{mm}^{3} / \mathrm{mm}^{2}\right)$ in the specimens increased with the square root of time. This test was chosen as it measures the rate of ingress of water through unsaturated concrete specimen. Therefore, it can be considered as a measure of water transport associated with capillary suction. The sorptivity is a material property characterizes the tendency of a material to absorb and transmit water by capillarity. Therefore, sorptivity test measures the rate of capillary suction at a specified time. The value of sorptivity illustrates the water mass uptake by concrete from the bottom surface. Lower the value of sorptivity, the higher the resistance of concrete towards water absorption. Sorptivity measurements may be used to classify the quality of the concrete.

The schematic arrangement of the sorptivity test is shown in Figure 1. The specimens for sorptivity test was preconditioned in an oven at $105 \pm 5{ }^{\circ} \mathrm{C}$ for $24 \mathrm{~h}$. Cubic specimens $(100 \times 100 \times 100 \mathrm{~mm})$ were placed in tray such that their bottom surface up to a height of $3-5 \mathrm{~mm}$ is in contact with water. In order to maintain accuracy of the results, the lower parts of the sides of the specimens adjoining the inflow face were sealed with an adhesive tape up to the height of 35-40 mm from the bottom of the cylinder. This procedure was considered to allow free water movement through the bottom surface. The total surface area of water within the tray should not be less than 10 times that of the specimen cross sectional area. Specimens were removed from the tray and weighed at intervals of 5, 10, 30, 60, 120, and $180 \mathrm{~min}$. The volume of water absorbed per unit cross sectional area at each time interval was evaluated and the sorptivity determined from the slope of the graph of the water absorbed against the square root of time.

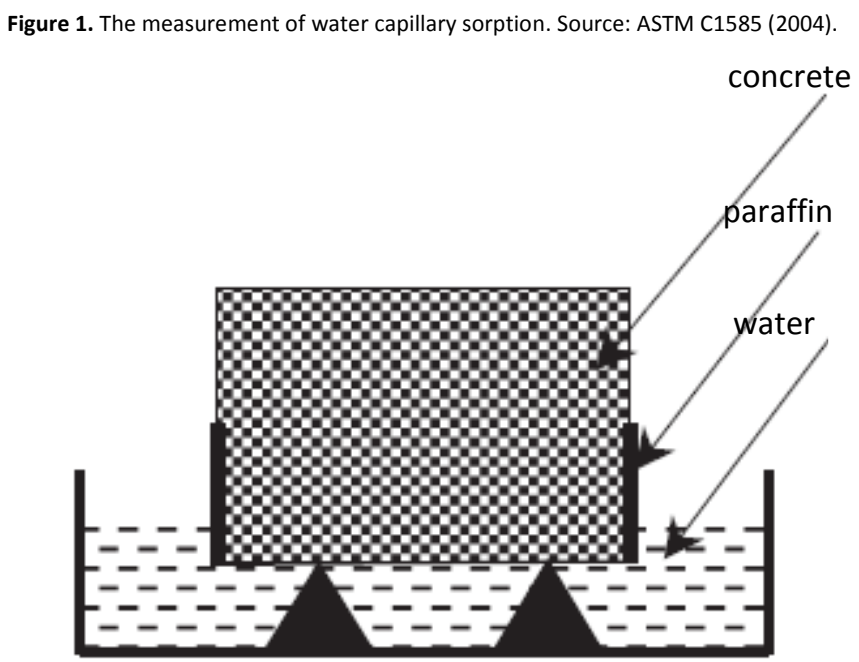

\section{Design of experiments}

Design of experiments is a form of analysis tool used to determine the influence of experimental variables on the experimental results (Davim, 2001). The selection of the control factors is the most important stage in the design of experiment. As many as possible should be included, so that it would be possible to determine non-significant variables at the earliest opportunity (Nian, Yang, \& Tarng, 1999). The Taguchi analysis method is found the optimum conditions of the factors that influence the experimental results (Ross, 1996). In order to apply Taguchi analysis methods to the solution of the problems in various areas, a systematic approach is needed. A systematic and efficient approach for this purpose is given in Figure 2. 
Figure 2. Flowchart of the systematic approach to the application of Taguchi methods. Source: Ross (1996)

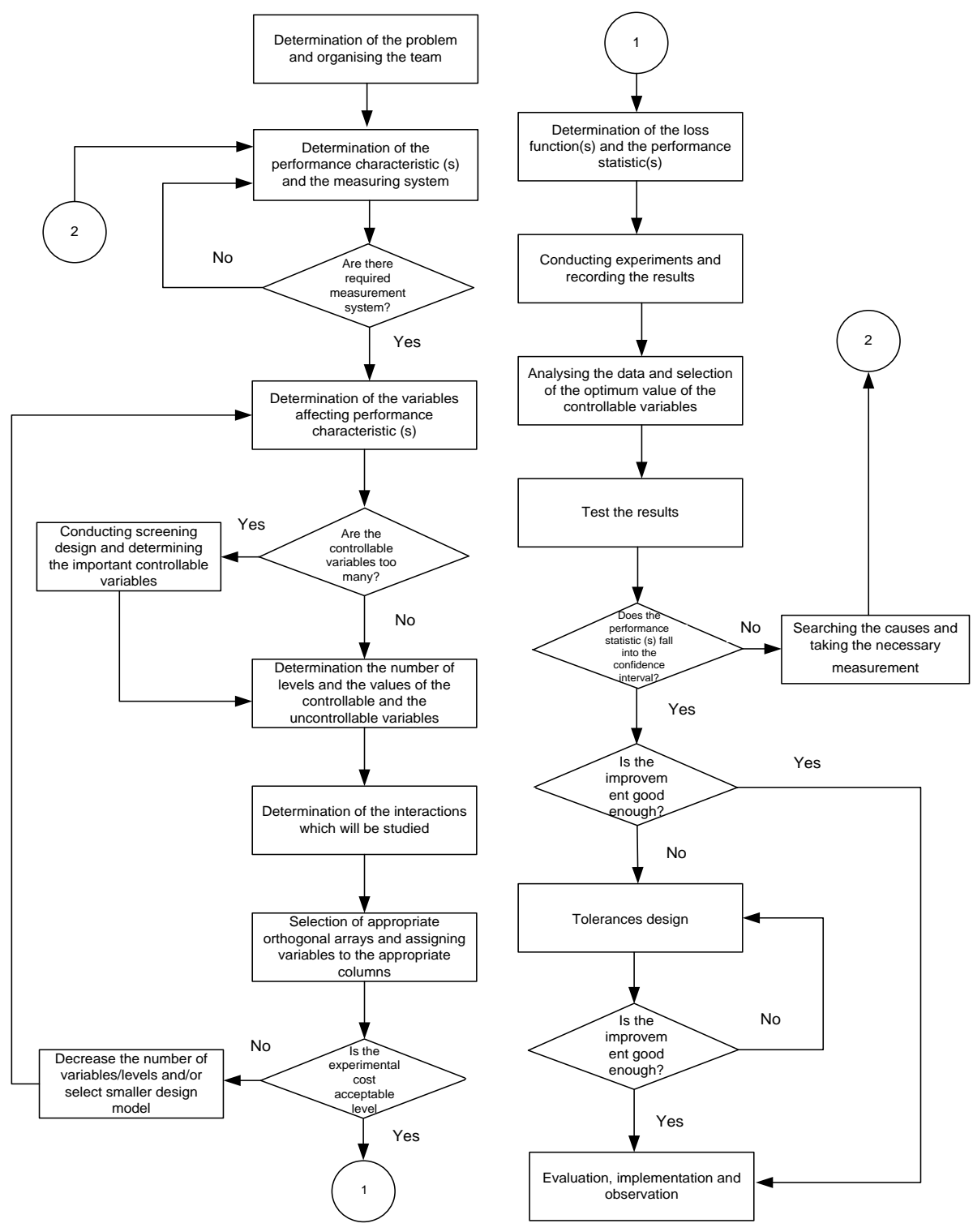

The operations of the flowchart can be grouped into thirteen operational steps for obtaining design optimization (Celik \& Burnak, 1998). The steps are:

- To determine of the problem and organizing the team,

- To determine of the performance characteristic(s) and the measuring system,

- Determination of the parameters affecting the performance characteristic(s),

- Conducting the screening design,

- Determination of the number of the values and levels of the controllable variables (parameters) and uncontrollable ones (parameters),

- Determination of the interactions to be examined,

- Selection of appropriate QAs and assigning the variables to the suitable columns,

- Determination of the loss function (s) and performance statistics,

- Conducting experiments and recording of results,

- Analyzing data and selection of the optimum value of the controllable variables,

- Testing the results,

- Establishing tolerance design, and

- Evaluation, implementation, and observation (Turkmen, Gul, \& Celik, 2008; Liao, 1997).

In general, strength and durability parameters will mainly depend on the manufacturing conditions employed. Table 3 shows the detail of the variables used in the experiment. It is noted that there are parameters at 3 levels. 


Table 3. Levels of the variables used in the experiments. Source: Own elaboration
\begin{tabular}{lccc}
\hline Variable & Level 1 & Level 2 & Level 3 \\
\hline $\begin{array}{l}\text { Cement Dosage } \\
\text { C }\left(\mathrm{kg} / \mathrm{m}^{3}\right)\end{array}$ & 260 & 320 & 400 \\
Fly ash, & & & \\
F (\%) & 0 & 10 & 17 \\
$\begin{array}{l}\text { Curing time } \\
\text { D (month) }\end{array}$ & 1 & 6 & 12 \\
\hline
\end{tabular}

Results and discussion

\section{Characterization of experimental results for Taguchi method and Anova analysis}

The changes of strength and durability properties of concrete are dependent on materials as well as environmental factors (such as initial strength or ultrasonic pulse velocity exposed to concrete, durability properties, and so on) are shown in Table 4. In this study, the specimens were used to investigate the most unfavorable situation (freeze-thaw and sulfate) for concrete containing type of class $C$ fly ash. Only 9 experiments are needed to study the entire experimental parameters using the $L_{9}\left(3^{4}\right)$ orthogonal array.

Table 4. L9 orthogonal array and experimental results. Source: Own elaboration.

\begin{tabular}{|c|c|c|c|c|c|c|c|}
\hline $\begin{array}{l}\text { Cement } \\
\text { Dosage }\end{array}$ & $\begin{array}{l}\text { Fly } \\
\text { Ash }\end{array}$ & $\begin{array}{l}\text { Curing } \\
\text { Time }\end{array}$ & Sorptivity & $\begin{array}{c}\text { Chloride ion } \\
\text { permeability }\end{array}$ & $\begin{array}{l}\text { Weight loss of } \\
\text { specimens } \\
\text { exposed to } \\
\text { freeze thaw }\end{array}$ & $\begin{array}{l}\text { UPV loss of } \\
\text { specimens } \\
\text { exposed to } \\
\text { freeze thaw }\end{array}$ & $\begin{array}{c}\text { Flexural } \\
\text { strength loss } \\
\text { of specimens } \\
\text { exposed to } \\
\text { freeze thaw }\end{array}$ \\
\hline 1 & 1 & 1 & 0.17662 & 2982 & 0.88 & 7.11 & 29.83 \\
\hline 1 & 2 & 2 & 0.12507 & 1306 & 2.08 & 5.1 & 27.14 \\
\hline 1 & 3 & 3 & 0.1446 & 1089 & 0.61 & 5.89 & 25.99 \\
\hline 2 & 1 & 2 & 0.1393 & 1769 & 1.17 & 5.38 & 27.62 \\
\hline 2 & 2 & 3 & 0.10456 & 788 & 0.91 & 4.74 & 21.17 \\
\hline 2 & 3 & 1 & 0.0916 & 740 & 0.91 & 4.56 & 19.46 \\
\hline 3 & 1 & 3 & 0.0778 & 680 & 1.22 & 3.8 & 28.08 \\
\hline 3 & 2 & 1 & 0.0586 & 350 & 1.21 & 3.44 & 20.1 \\
\hline 3 & 3 & 2 & 0.0439 & 243 & 1.51 & 3.56 & 18.48 \\
\hline
\end{tabular}

In this study, Anova was performed to evaluate statistically significant process parameters and percent contribution of the experimental parameters on the strength properties and durability parameters of concrete containing type of class C fly ash. Larger $\mathrm{F}$ value states that the variation of the process parameter makes significant on the performance characteristics (Celik \& Burnak, 1998; Lin, Wang, Yan, \& Tarng et al., 2000; Chan, Luo, \& Sun, 2000). In the Anova analysis, a loss function is used to calculate the deviation between the experimental value and the desired value. Some characteristics, such as sorptivity, chloride ion permeability, the ultrasonic pulse velocity percent change of concrete exposed to freeze-thaw, the flexural strength percent change of concrete exposed to freeze-thaw and the compressive strength percent change of concrete exposed to sulfate must be lower values. Such characteristics are named SmallerThe-Better type quality characteristics. Smaller the characteristics give the better performance in the strength and durability properties of concrete containing type of class C fly ash. Hence, the "smaller is better (LB)" loss function for strength properties was selected to found the optimal conditions. The loss function of this was shown in Equation 1.

$$
L_{i m}=\frac{1}{n} \sum_{s=1}^{n} y_{i m s}^{2}
$$

In Equation 1, $\operatorname{Lim}_{\text {im }}$ is the loss function of the ith performance characteristic for the $m$ th experiment, $n$ the number of tests, and $y_{i m s}$ the experimental value of the ith performance characteristics for the $m$ th experiment at the sth test. The loss function is further transformed into a signal-to-noise $(\mathrm{S} / \mathrm{N})$ ratio for determining the performance characteristic deviating from the desired value. The $\mathrm{S} / \mathrm{N}$ ratio was given in Equation 2. 


$$
n_{\text {im }}=-10 \log \left(L_{i m}\right)
$$

In Anova, degree of freedom is $(n-1), n$ represents the number of variables. The sum of the squares of factor $A\left(S_{A}\right)$ is expressed in Equation 3.

$$
S S_{A}=\frac{\sum n_{A i}^{2}}{N}-S S_{m}
$$

In Equation 3, $\mathrm{N}$ is the level of any A parameter. $\mathrm{n}$ is $\mathrm{S} / \mathrm{N}$ ratio. $\mathrm{SSm}$ is the sum of the squares of the average. Variance $\left(V_{A}\right)$ is found by dividing the sum of the squares of factor $A$ by the degree of freedom. The $F_{A 0}$ value shown in the table is the $\mathrm{F}$ test value of a factor. Factor $\mathrm{F}$ test value is given below Equation 4 .

$$
F_{A O}=\frac{V_{A}}{V_{e}}
$$

where here, $V_{A}$ is the variance of factor $A$. In addition, $V_{E}$ is the variance of the error.

$\mathrm{P}$ (percent contribution) is obtained by the ratio of the sum of the squares of that factor to the sum of the squares of all factors.

The percentage distribution of any factor is obtained by the ratio of the sum of the squares of that factor to the sum of the squares of all factors.

\section{Chloride ion permeability test}

Chloride ion penetration of all the concretes is determined by using rapid chloride ion permeability test. The total charge passing in $6 \mathrm{~h}$ as a measure of the chloride permeability is presented in Figure 3 . The chloride ion permeability limits suggested by ASTM C1202 were compared with the results (ASTM C1202, 1994). The results indicated that C332C102 mixture had the lowest chloride permeability, rated "very low" at 90 day. The total charge passed 243 coulombs for $\mathrm{C} 332 \mathrm{C} 102$ mixture. Among the mixtures, C260 mixture had the highest chloride permeability. Because that mixture had the lowest binder content rated "moderate" at $90 \mathrm{~d}$. It can be seen that the concretes which containing type of class $\mathrm{C}$ fly ash showed better performance than reference concretes. Similar results were observed by other researchers (Yigiter, Yazici, \& Aydin, 2017; Hooton \& Titherington, 2004; De Gutiérrez, Diaz, \& Delvasto, 2005). The chloride ion permeability of the concretes containing type of class C fly ash decreased when the fly ash content was increased. Moreover, the chloride ion permeability resistance increased with increasing of the cement dosage and increased with adding type of class $\mathrm{C}$ fly ash when cement dosage is constant. Using of fly ash can enhance the nature of the capillary pore system in concrete through its pozzolanic, physical and chemical effects both during the freshly mixed and subsequent hydrating states (Dhir \& Jones, 1999). The formation of a less porous, denser microstructure and a discontinuous pore system becomes critical for reduced chloride ion permeability values. The pozzolanic reactions seem to be able to develop a discontinuous pore system more easily. This could be the due to the fact that the chloride ion permeability depends on the chloride binding capacity of the constituent materials. In general, chlorides penetrate in concrete by diffusion along water paths or open pores. Some of these chlorides can react with the cement compounds, mainly tricalcium aluminates $\left(C_{3} A\right)$, forming stable chloro complexes. The excess of chloride is free and leads to the initiation of the corrosion process (Dinakar, Babu, \& Santhanam, 2008). 


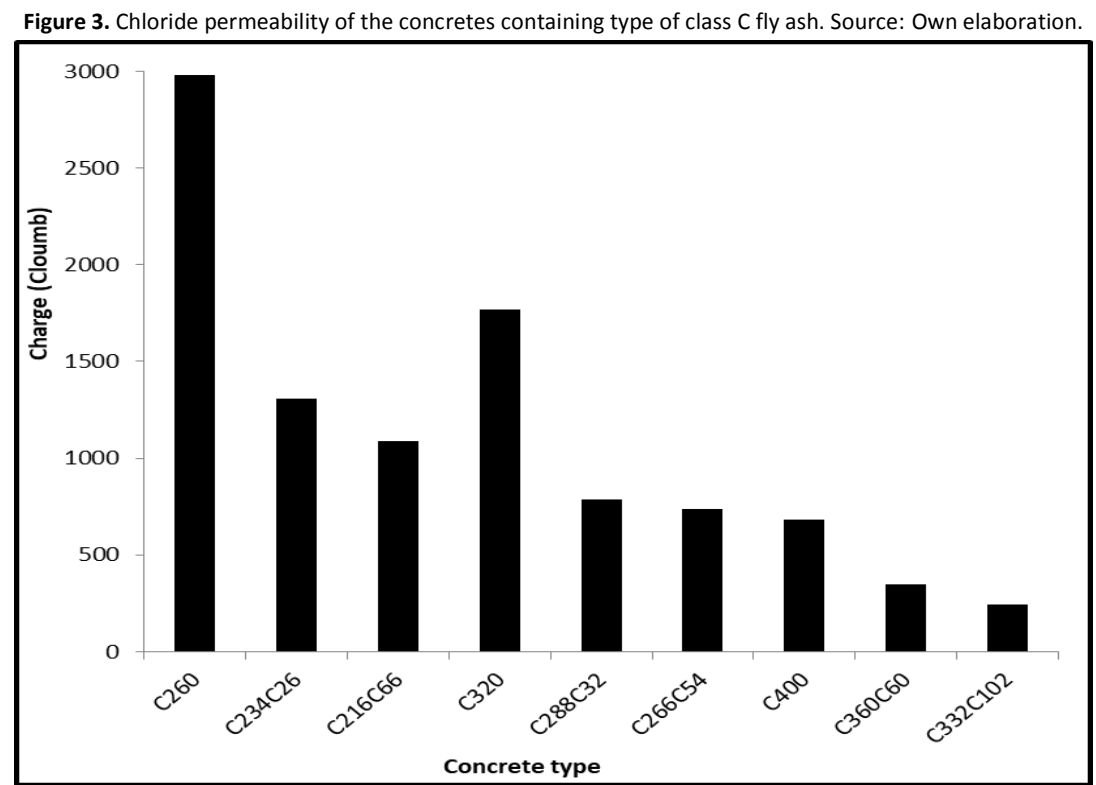

The presence of type of class $C$ fly ash leads to an increase for $C_{3} A$ due to the higher amount of alumina present in the mix and to an increase in the content of calcium silicate hydrate (C-S-H) that is formed in the pozzolanic reactions. Thus, the chloride binding capacity of concrete inclines to increase with type of class C fly ash addition and consequently less free chloride is available to initiate the corrosion process, as observed by some researchers (Koulombi, Batis, Malami, 1993). It can be clearly observed that the alumina content has a significant influence on the total charge of the concrete. As the alumina $\left(\mathrm{Al}_{2} \mathrm{O}_{3}\right)$ content increases the total charge decreases. The concrete specimens with replacements of type of class $C$ fly ash (with high amounts of alumina contents) result in increased resistance against chloride ion penetration (Dinakar et al., 2008).

Based on the $\mathrm{S} / \mathrm{N}$ ratio, the minimum chloride ion permeability was obtained $400 \mathrm{~kg} / \mathrm{m}^{3}$ cement dosage, $17 \%$ fly ash admixture and 6 month (Fig. 4). The results of variance (Anova) for the chloride ion permeability properties of concrete containing type of class $C$ fly ash are presented in Table 5. Degree of freedom is $(n-1), n$ represents the number of variables.

Figure 4. $\mathrm{S} / \mathrm{N}$ ratios of chloride ion permeability level. Source: Own elaboration.

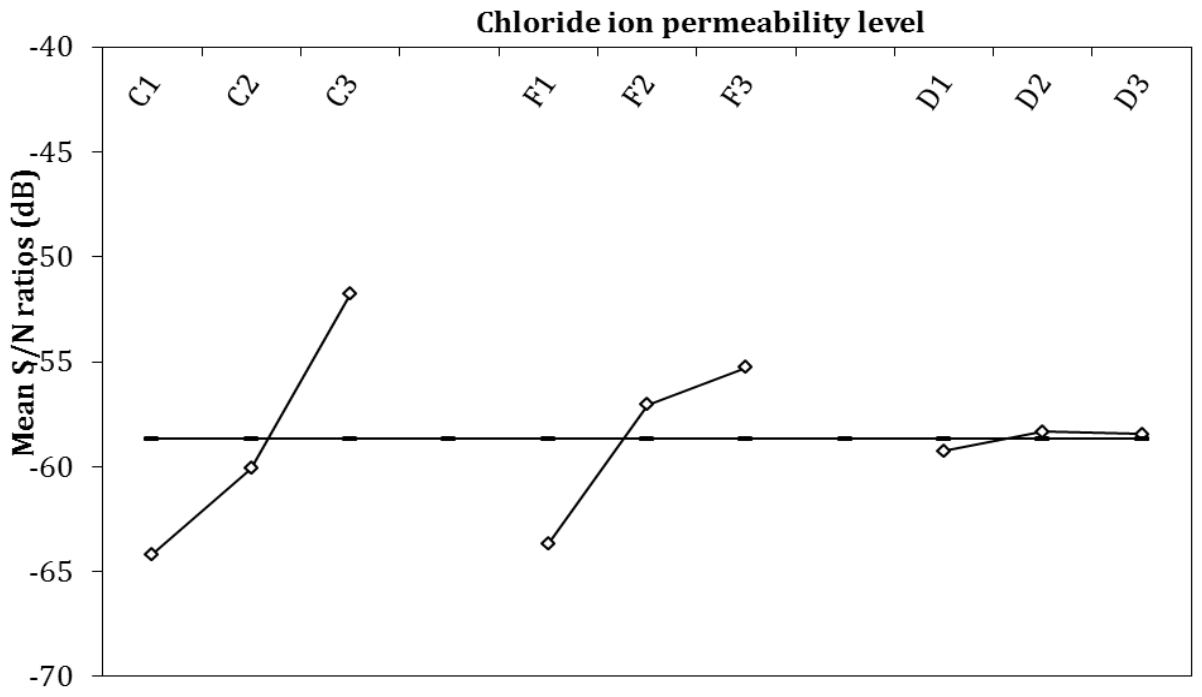

As shown in Table 5, the chloride ion permeability properties of containing concrete containing type of class $C$ fly ash have obtained higher $F_{\text {Ao }}$ values. The analysis indicated that the experimental error was very low at a level of $0.1 \%$. Table 5 shows the relative importance of the experimental parameters used in this study on the chloride ion permeability properties of containing concrete containing type of class C fly ash. It is clear that the cement dosage has an utmost importance on chloride ion penetration. 
Table 5. Results of Anova for chloride ion permeability. Source: Own elaboration.

\begin{tabular}{lccccc}
\hline Control factor & $\begin{array}{c}\text { Degrees of } \\
\text { freedom }(f)\end{array}$ & $\begin{array}{c}\text { Sum of } \\
\text { square }\left(\mathrm{SS}_{\mathrm{A}}\right)\end{array}$ & Variance $\left(V_{A}\right)$ & $F_{A 0}$ & Contribution (\%) \\
\hline $\begin{array}{l}\text { Cement Dosage } \\
\mathrm{C}\left(\mathrm{kg} / \mathrm{m}^{3}\right)\end{array}$ & 2 & 241 & 120.5 & 598.4 & 66.7 \\
$\begin{array}{l}\text { Fly Ash, F (\%) } \\
\text { Curing Time, D } \\
\text { (month) }\end{array}$ & 2 & 118.3 & 59.1 & 293.7 & 32.8 \\
Error & 2 & 1.5 & 0.8 & 3.8 & 0.4 \\
Total & 8 & 0.4 & 0.2 & -- & 0.1 \\
\hline
\end{tabular}

\section{Sorptivity}

Sorptivity test was performed for all nine mixtures after a $90 \mathrm{~d}$ curing period with the results shown in Figure 5 . The sorptivity defines the tendency of unsaturated concrete to absorb and transmit water by capillarity (Siddique \& Kadri, 2011). This test characterizes the possible macroscopic pore structure changes as a measurement of the changes in mass for partially submerged specimens. Sorptivity is the mass of water per unit area that can be absorbed in the material capillary when the specimen is in contact with water. It represents effective porosity that is accessible to water and, therefore, to aggressive environmental agents (Hanžič \& Ilić, 2003). When a homogeneous porous material has a constant hydraulic potential at its wet surface, liquid can reach the significant heights because of the capillary absorption (Yildirim, llica, \& Sengul, 2011). Water absorption through capillarity is a phenomenon that is due to the difference between the fluid's surface capillary pressure and its gravity pressure, which induces fluid movement until a balance is established. Capillary pressure increases with decreasing capillary diameter and is most relevant at the boundaries of concrete elements. The process is particularly visible in dry-wet conditions and has the most relevance near the element's surface (Evangelista \& De Brito, 2010). One of the important results of this study is that the sorptivity of the concretes containing type of class C fly ash decreased with the increase in fly ash content for each series. In addition, the sorptivity of the concretes decreased with an increase in the cement dosage and binder content. Among the mixtures, C260 mixture showed the highest sorptivity and C332C102 mixture showed the lowest sorptivity at 90 day. Similar behaviour has been reported for concrete by Martys and Ferraris (Martys \& Ferraris, 1997).

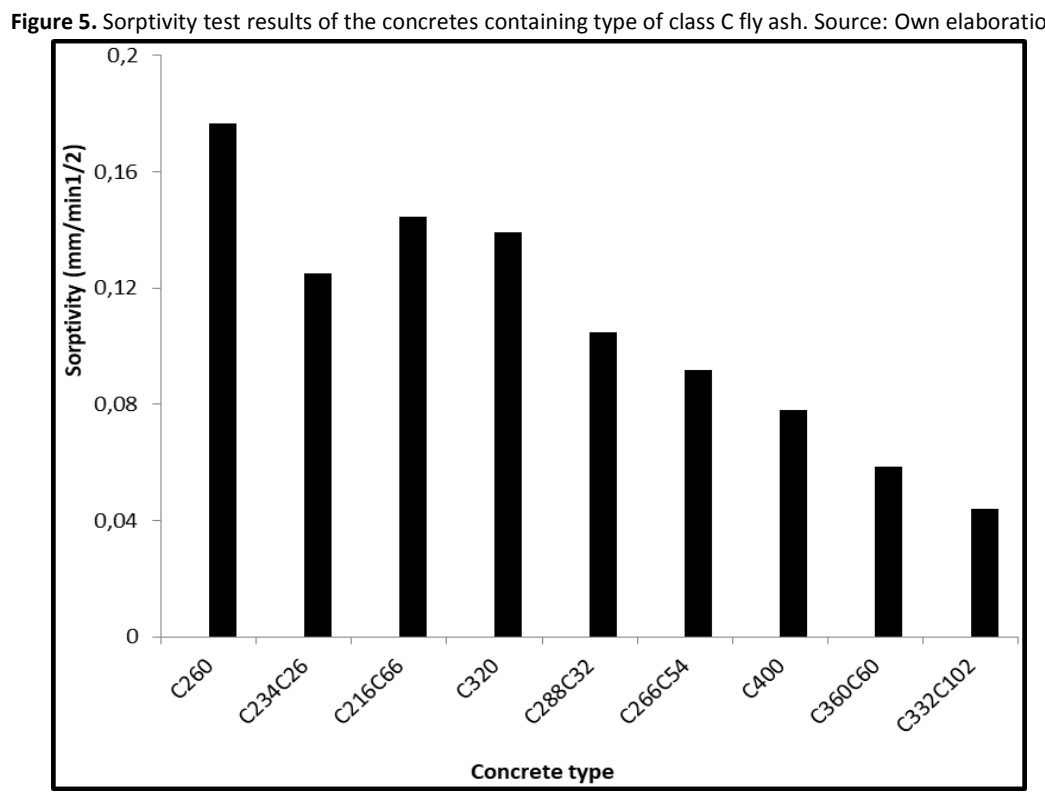

Joseph \& Ramamurthy (2009) have examined the sorptivity of the concretes incorporating fly ash. In that study, concrete with a cement content of $450 \mathrm{~kg} / \mathrm{m}^{3}$ and water content of $175 \mathrm{~kg} / \mathrm{m}^{3}$ was chosen as the reference mixture. Three levels of cement replacement with fly ash $10 \%, 30 \%$ and $50 \%$ by weight of cement were adopted. They have reported that there was a similar behavior in sorptivity till $30 \%$ fly ash replacement ratio compared to reference concrete (Joseph, \& Ramamurthy, 2009). The reason of lower sorptivity of the concretes containing type of class C fly 
ash compared to reference concretes for each series, can be consisted in the pozzolanic reaction. Type of class $C$ fly ash has reacted with free lime $(\mathrm{CaO})$ during hydration and occurred additional tobermorite gels to the silicate gels of cement. Thus, capillary pores of fly ash additive concretes are filled. Therefore, sorptivity of these specimens is lower than the reference concretes for each series due to decrement of capillary pores. Moreover, filling the voids in a packed system may improve the arrangement of particles in the system, ensuring a better contribution of the interfaced to achieve adequate prevent on the concretes of sorptivity (Yahia, Tanimura, \& Shimoyama, 2005). The better packing of type of class $\mathrm{C}$ fly ash particles in the fresh state leading to an overall reduced sorptivity of the concretes after hydration. However, it was verified that the addition of type of class $\mathrm{C}$ fly ash to the mixtures containing various cement contents quite was beneficial, bringing a substantial improvement of the sorptivity behavior of the concretes.

Based on the $\mathrm{S} / \mathrm{N}$ ratio, the minimum sorptivity level was obtained $400 \mathrm{~kg} / \mathrm{m}^{3}$ cement dosage, $17 \%$ fly ash admixture and 6 month (Fig. 6). The results of Variance (Anova) for the sorptivity level of concrete containing type of class $C$ fly ash are presented in Table 6.

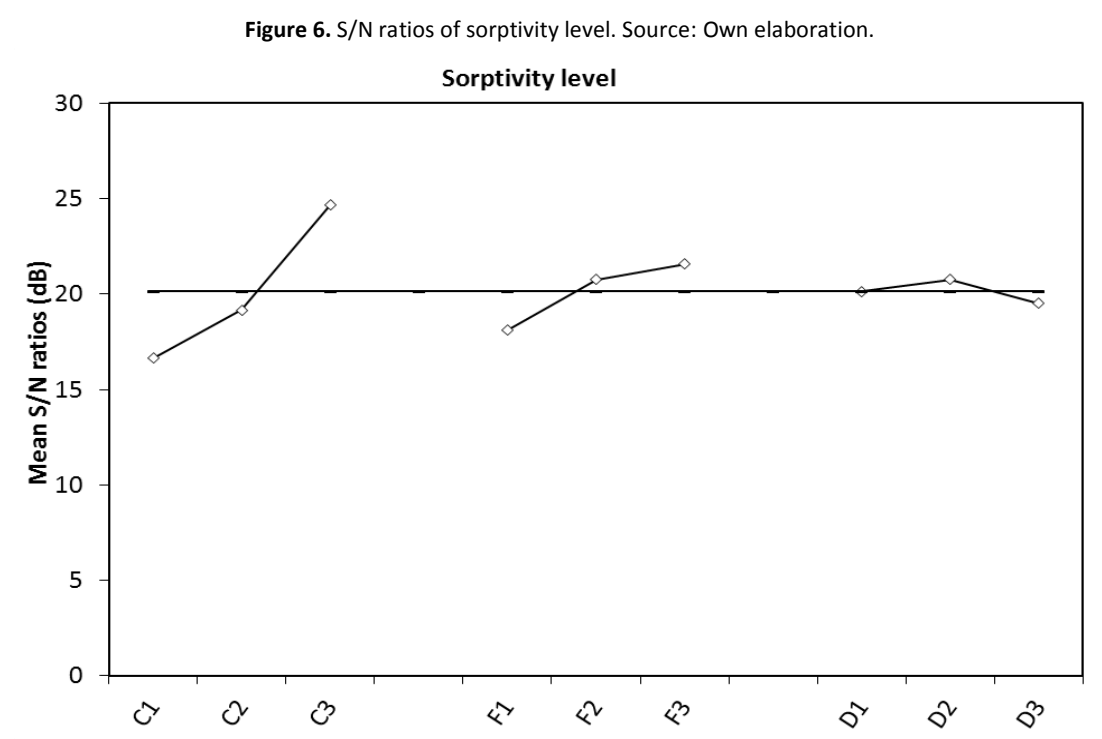

As shown in Table 6, the sorptivity levels of containing concrete containing type of class C fly ash have obtained higher $F_{\text {Ao }}$ values. The analysis showed that the experimental error was very low at a level of $1.5 \%$. Table 6 shows the relative importance of the experimental parameters used in this study on the sorptivity levels of containing concrete containing type of class C fly ash. It is clear that the cement dosage has an utmost importance on sorptivity level.

Table 6. Results of Anova for sorptivity. Source: Own elaboration.

\begin{tabular}{lccccc}
\hline \multicolumn{7}{c}{ Table 6. Results of Anova for sorptivity. Source: Own elaboration. } \\
\hline $\begin{array}{l}\text { Degrees of } \\
\text { freedom }(f)\end{array}$ & $\begin{array}{c}\text { Sum of } \\
\text { square }\left(\mathrm{SS}_{\mathrm{A}}\right)\end{array}$ & Variance $\left(V_{A}\right)$ & $F_{A O}$ & $\begin{array}{c}\text { Contribution } \\
(\%)\end{array}$ \\
\hline $\begin{array}{l}\text { Cement Dostor } \\
\text { C }\left(\mathrm{kg} / \mathrm{m}^{3}\right)\end{array}$ & 2 & 100.9 & 50.4 & 52.6 & 80.9 \\
Fly Ash, F (\%) & 2 & 19.6 & 9.8 & 10.2 & 15.7 \\
Curing Time, D & 2 & 2.3 & 1.2 & 1.2 & 1.9 \\
Error & 2 & 1.9 & 1 & -- & 1.5 \\
Total & 8 & 124.7 & 62.4 & 64 & 100 \\
\hline
\end{tabular}




\section{Freezing-thawing resistance}

\section{Change in weight after exposure to freezing-thawing cycles}

The experimental results of the weight change of the concretes containing class $C$ fly ash under the freezing-thawing cycles are given in Figure 7. The weight of the specimens after 300 cycles of freeze-thaw did not show a stunning reduction. The rate of weight loss of concrete increased when increasing the replacement level of type of class $C$ fly ash. So, the highest weight loss was found in the concretes containing higher level of class $\mathrm{C}$ fly ash. The weight losses of the specimens were in the range of $0.61 \%-2.07 \%$ after freezing-thawing cycles for C260 series. For C320 series, class C fly ash additive concretes showed weight loss values in the range of $0.90 \%-1.17 \%$. In terms of weight loss, type of class C fly ash additive concretes exhibited weight loss in the range of $1.20 \%-1.51 \%$ for C400 series. When cement content was increased it can be seen that the weight loss of the specimens also increased and reference concretes had lower weight loss values compared with the specimens containing class $C$ fly ash for each series.

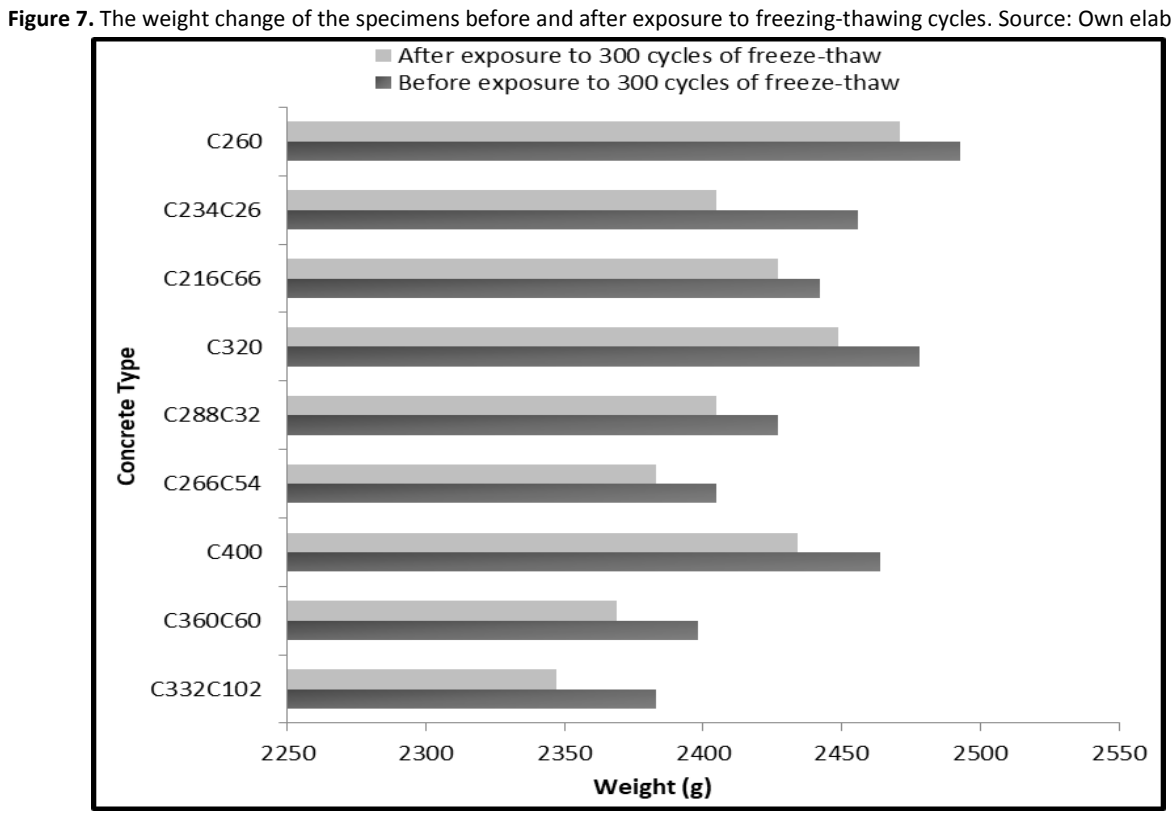

This fact would be in agreement with data published by Siddique (Siddique, 2011) who examined the freezing-thawing resistance of concretes in terms of weight loss containing various replacement rates of fly ash. The weight variation during freezing-thawing cycles is due to water movement in and out of the specimen and cracking. As soon as microcracking takes place, the deteriorated zones filled with the surrounding water will cause an increase in the weight of the specimen (Gokce, Nagataki, Saeki, \& Hisada, 2004). But, test results showed that all the specimens indicated weight loss after freezing-thawing cycles. The weight loss caused by the desquamation of concrete surface was observed with freezing-thawing cycles (Figure 8). In actual concrete structures, concrete surface scaled markedly when exposed to freezing-thawing cycles caused by the change of climate.

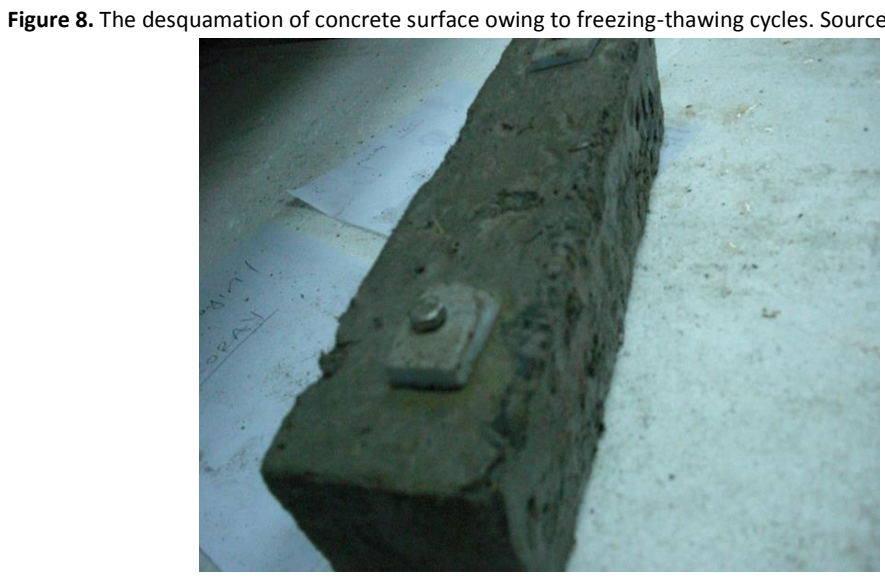


Based on the $\mathrm{S} / \mathrm{N}$ ratio, The minimum weight loss was obtained $320 \mathrm{~kg} / \mathrm{m}^{3}$ cement dosage, $17 \%$ fly ash admixture and 12 month (Figure 9). The results of Variance (Anova) for the weight loss of concrete containing type of class $C$ fly ash are presented in Table 7.

Figure 9. S/N ratios of weight loss level. Source: Own elaboration.

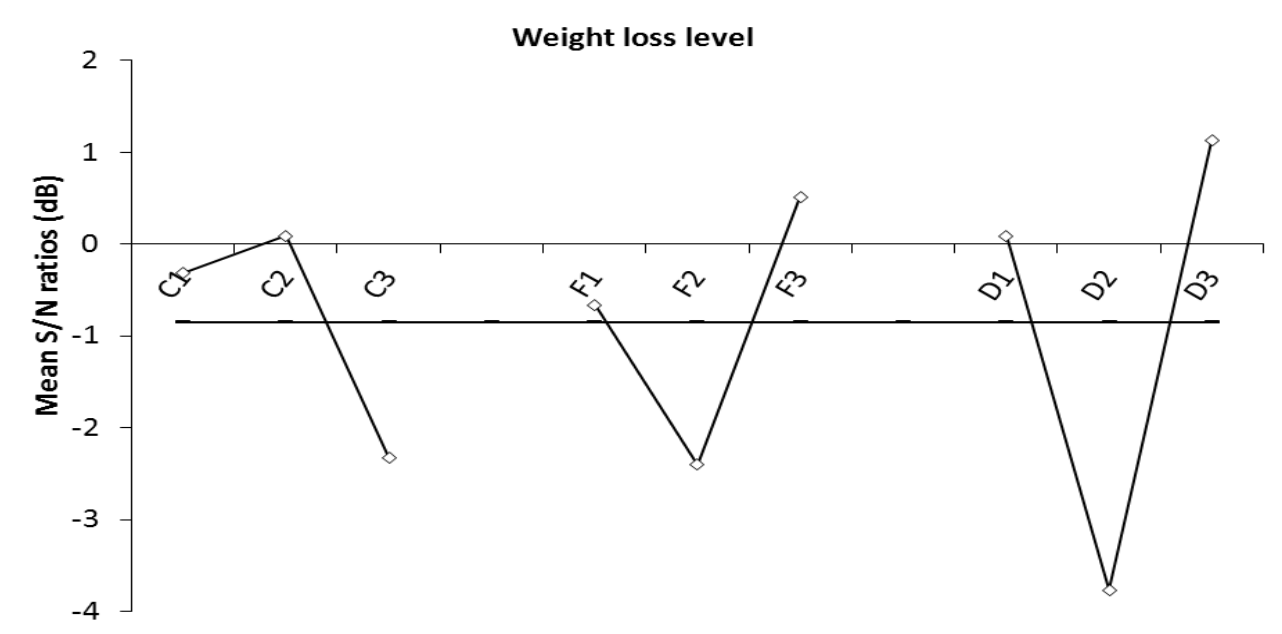

As shown in Table 7, the analysis indicated that the experimental error was low at a level of $16.7 \%$. Table 6 shows the relative importance of the experimental parameters used in this study on the weight loss of containing concrete containing type of class $\mathrm{C}$ fly ash. It is clear that the fly ash has an utmost importance on weight loss.

\begin{tabular}{|c|c|c|c|c|c|}
\hline Control factor & $\begin{array}{l}\text { Degrees of } \\
\text { freedom }(f)\end{array}$ & $\begin{array}{c}\text { Sum of } \\
\text { square }\left(\mathrm{SS}_{\mathrm{A}}\right)\end{array}$ & $\begin{array}{l}\text { Variance } \\
\qquad\left(V_{A}\right)\end{array}$ & $F_{A O}$ & $\begin{array}{c}\text { Contribution } \\
(\%)\end{array}$ \\
\hline $\begin{array}{l}\text { Cement Dosage } \\
\mathrm{C}\left(\mathrm{kg} / \mathrm{m}^{3}\right)\end{array}$ & 2 & 10 & 5 & 0.8 & 13.2 \\
\hline Fly Ash, F (\%) & 2 & 12.9 & 6.4 & 1 & 17.1 \\
\hline $\begin{array}{l}\text { Curing Time, D } \\
\text { (month) }\end{array}$ & 2 & 39.9 & 19.9 & 3.2 & 53 \\
\hline Error & 2 & 12.6 & 6.3 & -- & 16.7 \\
\hline Total & 8 & 75.4 & 37.6 & 5 & 100 \\
\hline
\end{tabular}

\section{Change in UPV after exposure to freezing-thawing cycles}

In this part, the durability of the concretes containing type of class C fly ash to the repeated cycles of freezing and thawing was determined from changes in UPV of the test specimens before and after the freezing-thawing cycles. The UPV through a material is a function of the elastic modulus and density of the material. The UPV can therefore be used to determine the uniformity and quality of the material. Figure 10 shows the results obtained from the UPV measurements of all the specimens subjected to freezing-thawing cycles. Each data point represents the average of three measurements. The rate of reduction in the UPV of the specimens did not changed significantly when increasing the replacement level of type of class $\mathrm{C}$ fly ash. The rate of reduction in the UPV of the specimens was in the range of $5.89 \%-7.11 \%$ after freezing-thawing cycles for C260 series. For C320 series, type of class C fly ash additive concretes showed the rate of reduction in the UPV in the range of $4.56 \%-5.38 \%$. In terms of the rate of reduction in the UPV, type of class $\mathrm{C}$ fly ash additive concretes exhibited the rate of reduction in the UPV in the range of $3.44 \%-3.80 \%$ for C400 series. When cement content was increased it can be seen that the rate of reduction in the UPV of the specimens also decreased and reference concretes had higher the rate of reduction in the UPV compared with the specimens containing type of class C fly ash for each series. Consequently, there was a notable reduction in the UPV after the specimens are subjected to freezing-thawing cycles. Sabir have investigated the freezing-thawing resistance of concretes in terms of the rate of reduction in the UPV containing silica fume and found similar results (Sabir \& Kouyiali, 1991). While the freezing of water damages the concrete, it is not the main contributor to the freezing and thawing deterioration of concrete. The primary damage is caused by the increase in hydraulic pressure within the pore 
spaces. However, if the distance to a void is too great and the hydraulic pressure cannot be relieved, the water pressure will expand the pores causing tensile stresses in the surrounding concrete paste. In saturated concrete, the tensile stresses may eventually exceed the tensile capacity of the concrete and cracking will occur. It is obvious that the transmission of pulse waves through a concrete mass is highly influenced by the cracking of concrete. Thus, the decrease in pulse velocity with increasing freezing-thawing cycles is a sensitive measure of the progress of cracking in the material. Due to more cracks in concrete pulse velocity delays to reach from transmitter to receiver (Yuksel et al., 2011). Therefore, cracks caused the reduction of pulse velocity and results in low UPV values.

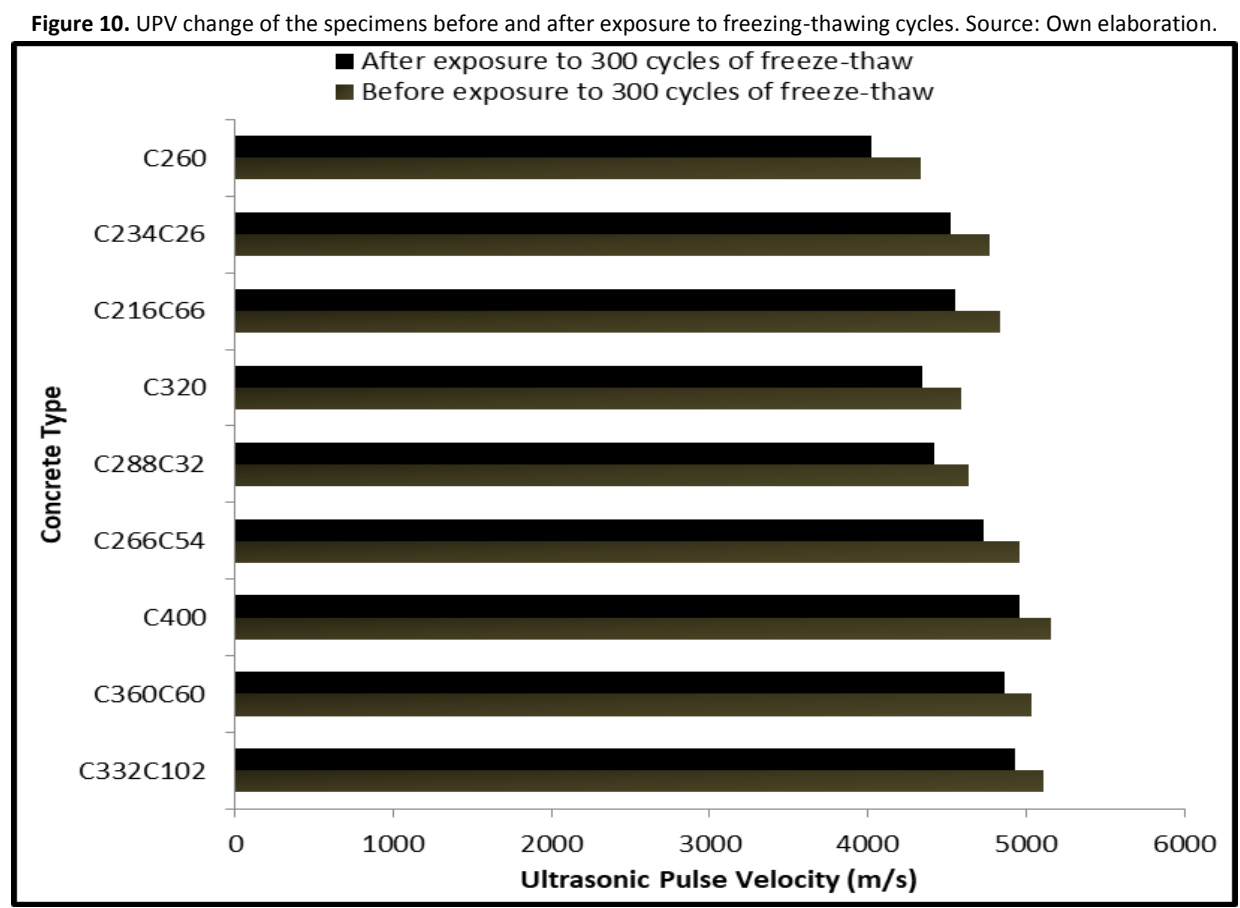

Based on the $\mathrm{S} / \mathrm{N}$ ratio, the minimum ultrasonic pulse velocity loss was obtained $400 \mathrm{~kg} / \mathrm{m}^{3}$ cement dosage, $10 \%$ fly ash admixture and 6 month (Figure 11). The results of Variance (Anova) for the ultrasonic pulse velocity loss of concrete containing type of class $\mathrm{C}$ fly ash are presented in Table 7.

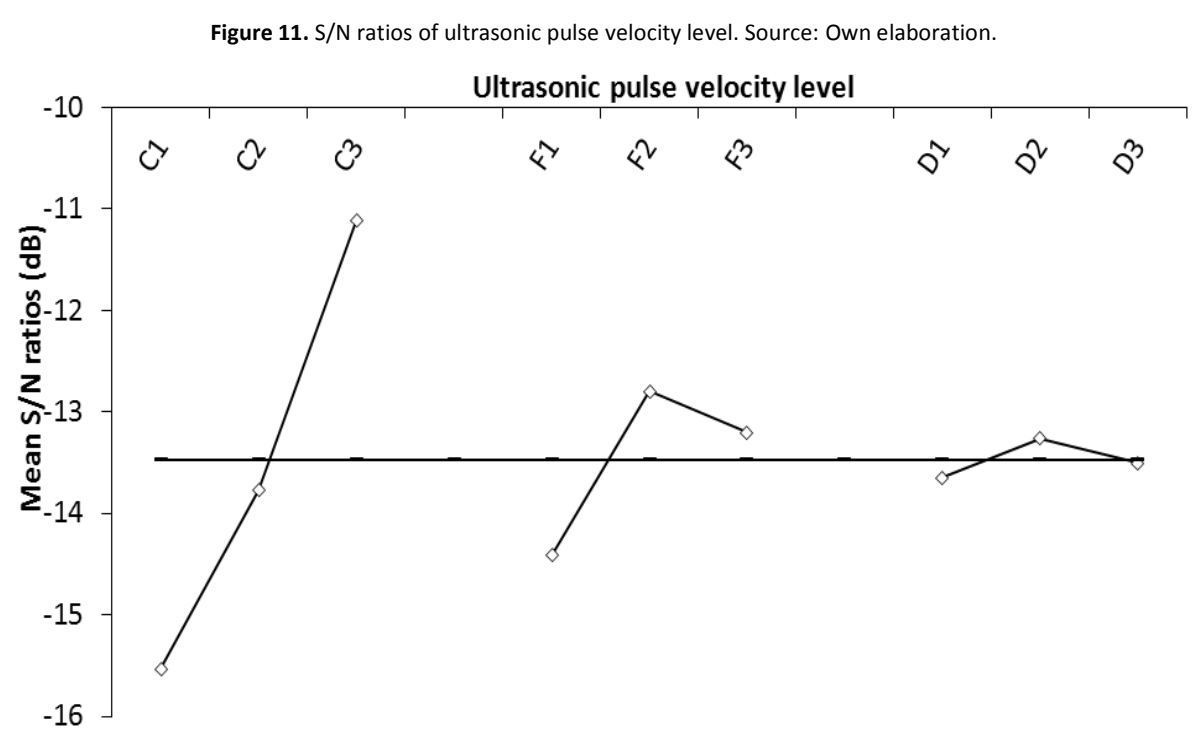

The analysis showed that the experimental error was very low at a level of $3.5 \%$. Table 8 shows the relative importance of the experimental parameters used in this study on the ultrasonic pulse velocity loss of containing concrete containing type of class $\mathrm{C}$ fly ash. It is clear that the cement dosage has an utmost importance on ultrasonic pulse velocity loss. 
Table 8. Results of Anova for ultrasonic pulse velocity loss. Source: Own elaboration.

\begin{tabular}{lccccc}
\hline Control factor & $\begin{array}{c}\text { Degrees of } \\
\text { freedom }(f)\end{array}$ & $\begin{array}{c}\text { Sum of } \\
\text { square }\left(\mathrm{SS}_{\mathrm{A}}\right)\end{array}$ & $\begin{array}{c}\text { Variance } \\
\left(V_{A}\right)\end{array}$ & $\begin{array}{c}\text { Contribution } \\
(\%)\end{array}$ \\
\hline $\begin{array}{l}\text { Cement Dosage } \\
\mathrm{C}\left(\mathrm{kg} / \mathrm{m}^{3}\right)\end{array}$ & 2 & 29.6 & 14.8 & 24.1 & 83.8 \\
$\begin{array}{l}\text { Fly Ash, F (\%) } \\
\text { Curing Time, D } \\
\text { (month) }\end{array}$ & 2 & 4.2 & 2.1 & 3.4 & 12.1 \\
Error & 2 & 0.2 & 0.1 & 0.2 & 0.6 \\
Total & 8 & 1.2 & 0.6 & -- & 3.5 \\
\hline
\end{tabular}

\section{Change in flexural strength after exposure to freezing-thawing cycles}

Figure 12 shows flexural strength change of the specimens before and after exposure to freezing-thawing cycles. After freezing-thawing cycles, the amounts of flexural strength loss have been measured in the range of $6.70 \%-29.83 \%$ for the concretes containing type of class $\mathrm{C}$ fly ash. The flexural strength loss decreased for each series as the replacement of type of class C fly ash increased; For example, the flexural strength loss of $\mathrm{C} 332 \mathrm{C} 102$, was about $6.70 \%$, compared to flexural strength loss of $9.98 \%$ for reference specimen for C400 series. C288C32 mixture had the lowest flexural strength loss $(19.46 \%)$ and reference specimen had the highest one $(21.17 \%)$ for C320 series. C234C26 mixture (27.62 \%) performed the best performance as flexural strength loss after freezing-thawing cycles and reference mixture $(29.83 \%)$ showed the worst performance for C260 series. These results indicate that the incorporation of type of class C fly ash leads to reduced flexural strength loss compared with those having only Portland cement (reference mixtures for each series). Moreover, it is clear that the mixtures containing more cement and binder content exhibited a much better resistance to repeated freezing-thawing cycles. Reference mixtures exhibited sensitivity in terms of flexural strength reduction after freezing-thawing cycles because of a less refined matrix for each series. The main reason for the flexural strength loss after repeated freezing-thawing cycles can be explained by some physical events. Freezing-thawing action degrades concrete mainly due to the hydraulic pressures associated with the expansion of water into ice which requires a greater volume inside the concrete. When water freezes there is a $9 \%$ increase in volume as water turns to ice. However, water that is trapped within the capillary pores of concrete does not necessarily freeze at $0{ }^{\circ} \mathrm{C}$.

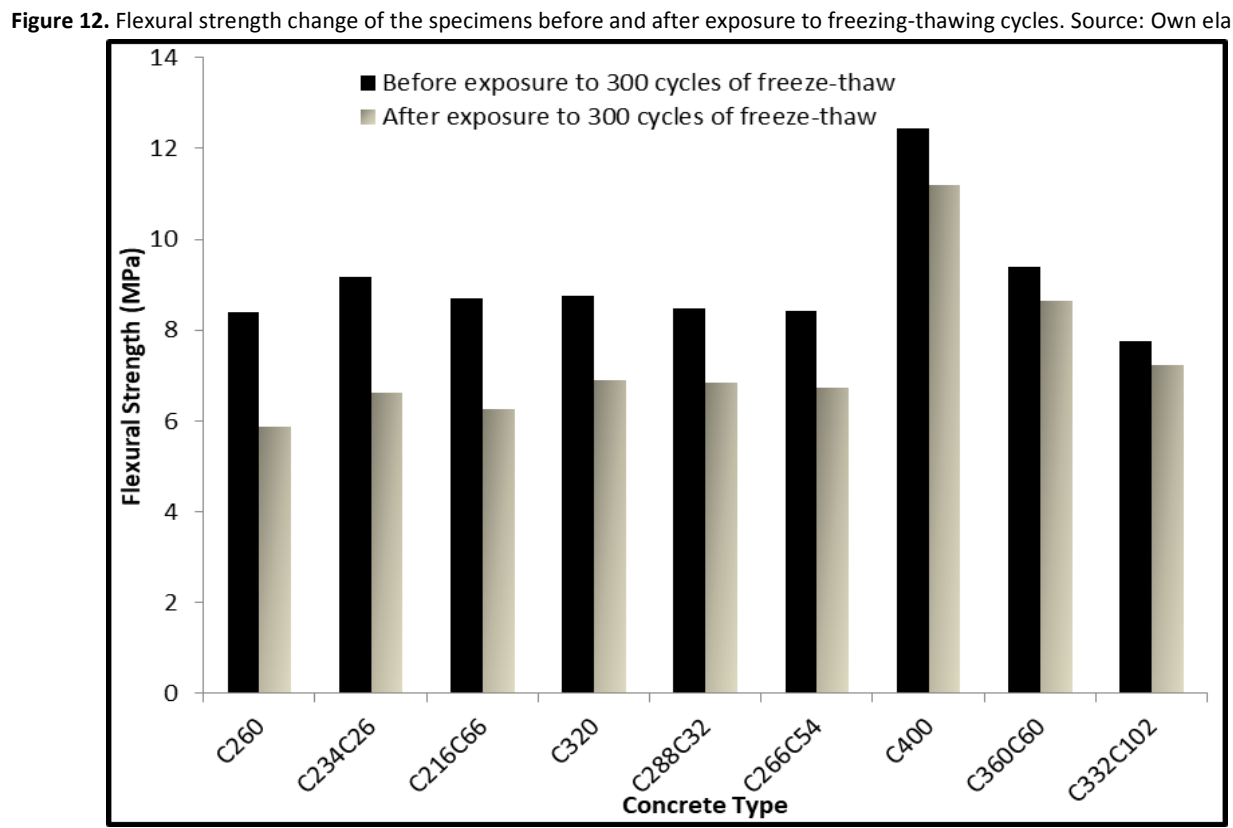


The water in the capillary pores of concretes expands upon freezing. If the required volume is greater than the space available, the excess water is driven off by the pressure of expansion (Shang et al., 2008). The magnitude of this hydraulic pressure depends on the permeability of the concrete, the degree of saturation, the distance to the nearest unfilled void and the rate of freezing. If the pressure exceeds the tensile strength of the paste at any point, it will cause local cracking. In repeated cycles of freezing-thawing in a wet environment, water will enter the cracks during the thawing portion of the cycle only to freeze again later, and there will be progressive deterioration with each freezing-thawing cycle (Shang et al., 2008). The number of microcosmic cracks increased and the width of the microcosmic cracks became broad with freezing-thawing cycles. Considering the concrete specimen under loads, the initiation and growth of every new crack will reduce the load carrying area. This reduction in load carrying area further causes an increase in the stress concentration at critical crack tips. So, the main reason for inducing cracks on the freezing-thawing cycles of concrete is the freezing of water and its expansion. The second is the thermal stress developed during the repeated freezing-thawing action (Shang et al., 2009). However, the flexural strength of the specimens containing type of class $C$ fly ash decreased when freezing-thawing cycles were repeated. Cracks are mainly created within the cement paste, the interface between cement paste and aggregate. As pozzolanic materials, type of class $C$ fly ash causes the formation of a less porous, denser microstructure. Moreover, these pozzolanic materials play an important role in improving the aggregate-paste bond through the densification of the transition zone and formation of more calcium silicate hydrates (Shannag et al., 2003). Due to pozzolanic reaction, the water was not allowed to pass by filling the pores. So, the use of type of class $\mathrm{C}$ fly ash retained less water for freezing-thawing cycles compared to control concrete. Yazici have examined the use of type of class $C$ fly ash on the freezing-thawing resistance of the concrete and reported that freezing-thawing effect caused reduction in splitting tensile strength and compressive strength at all fly ash content (Yazici, 2008). Sabir have investigated frost resistance properties of silica fume additive concretes by observing the flexural and compressive strength losses. According to the results for the flexural and compressive strengths, the exposure to freezing and thawing results in considerable reductions (10 \% - 20 \%) in the values obtained at 28 day (Yüksel et al., 2011). Similar results were observed by Yuksel et al. (2007).

Based on the $\mathrm{S} / \mathrm{N}$ ratio, the minimum flexural strength loss was obtained $400 \mathrm{~kg} / \mathrm{m}^{3}$ cement dosage, $17 \%$ fly ash admixture and 1 month (Figure 13). The results of variance (Anova) for the flexural strength loss of concrete containing type of class $\mathrm{C}$ fly ash are presented in Table 9.

As shown in Table 9, the analysis indicated that the experimental error was very low at a level of $4.2 \%$. Table 9 indicates the relative importance of the experimental parameters used in this study on the ultrasonic pulse velocity loss of containing concrete containing type of class C fly ash. It is clear that the fly ash has an utmost importance on flexural strength loss.

Figure 13. $\mathrm{S} / \mathrm{N}$ ratios of flexural strength level. Source: Own elaboration.

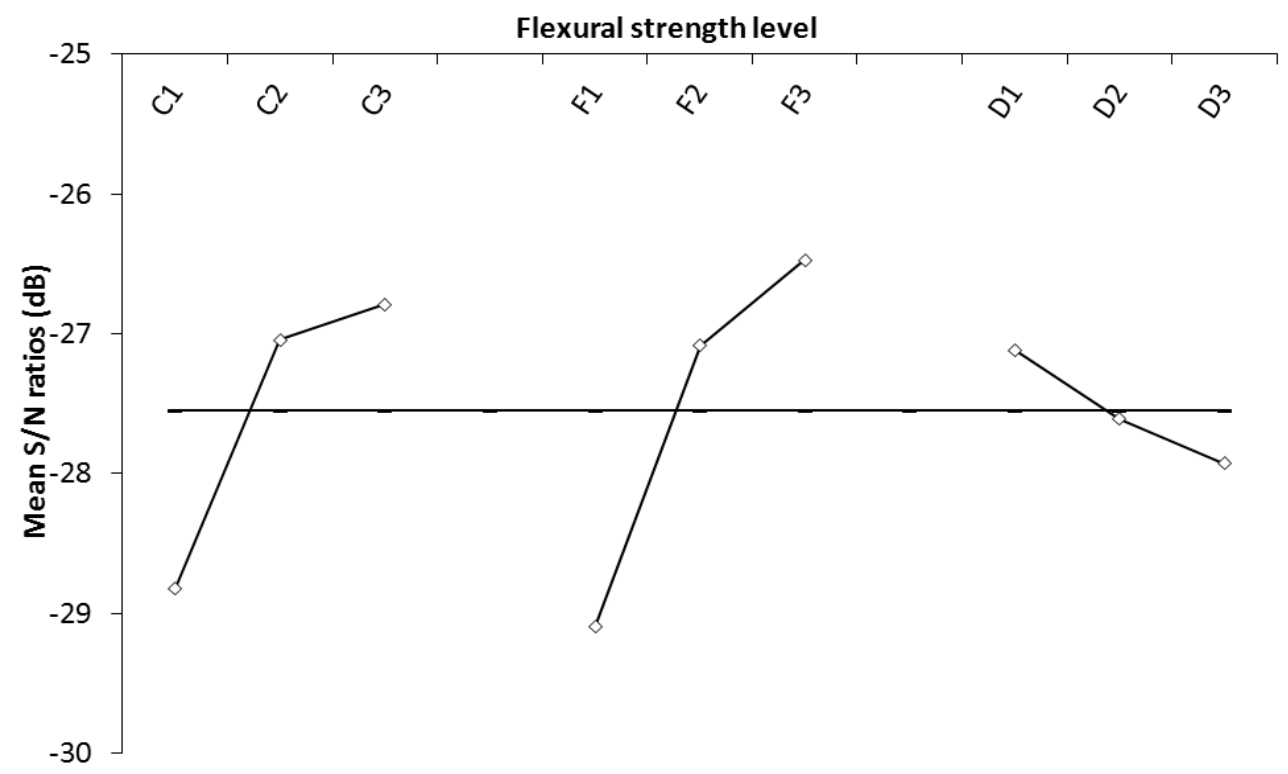


Table 9. Results of Anova for flexural strength loss. Source: Own elaboration.

\begin{tabular}{lccccc}
\hline Control factor & $\begin{array}{c}\text { Degrees of } \\
\text { freedom }(f)\end{array}$ & $\begin{array}{c}\text { Sum of } \\
\text { square }\left(\mathrm{SS}_{\mathrm{A}}\right)\end{array}$ & $\begin{array}{c}\text { Variance } \\
\left(V_{A}\right)\end{array}$ & $F_{A O}$ & $\begin{array}{c}\text { Contribution } \\
(\%)\end{array}$ \\
\hline $\begin{array}{l}\text { Cement Dosage } \\
\mathrm{C}\left(\mathrm{kg} / \mathrm{m}^{3}\right)\end{array}$ & 2 & 7.4 & 3.7 & 8.51 & 35.8 \\
$\begin{array}{l}\text { Fly Ash, F (\%) } \\
\begin{array}{l}\text { Curing Time, D } \\
\text { (month) }\end{array}\end{array}$ & 2 & 11.3 & 5.7 & 13.1 & 55.1 \\
$\begin{array}{l}\text { Error } \\
\text { Total }\end{array}$ & 2 & 1 & 0.5 & 1.2 & 4.9 \\
& 8 & 0.9 & 0.4 & -- & 4.2 \\
\hline
\end{tabular}

Laboratory tests were performed to determine the durability properties of the concretes containing type of class $C$ fly ash. Based on the experimental work in this study and the discussion about test results, the following conclusions can be drawn:

- The chloride ion permeability of the concretes containing type of class C fly ash decreased when the fly ash content was increased. The chloride ion permeability resistance increased with increasing of the cement and binder content and the concretes which containing type of class C fly ash showed better performance than reference mixtures. Chloride ion permeability test results were in the range of 243-2982 Cloumb and C332C102 mixture had the lowest chloride permeability at $90 \mathrm{~d}$.

- Sorptivity of the concretes containing type of class $\mathrm{C}$ fly ash decreased with the increase in fly ash content for each series. C332C102 mixture performed the lowest sorptivity at $90 \mathrm{~d}$ among the mixtures. The sorptivity of the concretes decreased with an increase in the cement dosage and binder content. The reason of lower sorptivity of the concretes containing type of class $\mathrm{C}$ fly ash compared to reference concretes for each series, can be consisted in the pozzolanic reaction.

- The weight of the specimens after freezing-thawing cycles did not show a remarkable reduction. C216C66 mixture performed the best resistance as the weight loss after freezing-thawing cycles. The rate of weight loss of concrete increased when increasing the replacement level of type of class C fly ash. When cement content was increased the weight loss of the specimens also increased and reference concretes had lower weight loss values compared with the specimens containing type of class $C$ fly ash for each series.

- The rate of reduction in the UPV of the specimens did not changed significantly when increasing the replacement level of type of class C fly ash. C360C60 mixture performed the best resistance as the reduction in the UPV after freezing-thawing cycles. The rate of reduction in the UPV of the specimens was in the range of \% $3.44-\% 7.11$ after freezing-thawing cycles. There was a notable reduction in the UPV after the specimens are subjected to freezingthawing cycles.

- After freezing-thawing cycles, the amounts of flexural strength loss have been measured in the range of $6.70 \%$ $29.83 \%$ for the mixtures containing type of class C fly ash. C332C102 mixture performed the best resistance as the flexural strength loss after freezing-thawing cycles. The incorporation of type of class $\mathrm{C}$ fly ash leads to reduced flexural strength loss compared with those having only Portland cement.

- Based on the $\mathrm{S} / \mathrm{N}$ ratio, the minimum sorptivity level and chloride ion permeability was obtained $400 \mathrm{~kg} / \mathrm{m}^{3}$ cement dosage, $17 \%$ fly ash admixture and 6 month. The minimum weight loss was obtained $320 \mathrm{~kg} / \mathrm{m}^{3} \mathrm{cement}$ dosage, $17 \%$ fly ash admixture and 12 month. The minimum ultrasonic pulse velocity loss was obtained $400 \mathrm{~kg} / \mathrm{m}^{3}$ cement dosage, $10 \%$ fly ash admixture and 6 month. The minimum flexural strength loss was obtained $400 \mathrm{~kg} / \mathrm{m}^{3}$ cement dosage, $17 \%$ fly ash admixture and 1 month.

- Based on the Anova, the cement dosage has an utmost importance on the sorptivity level, chloride ion permeability and ultrasonic pulse velocity loss. Furthermore, the fly ash percentage has an utmost importance on the weight loss, flexural strength loss. The analysis indicated that the experimental error was low level (0.1\% - $16.7 \%)$. 
Aldea, C. M., Young, F., Wang, K., \& Shah, S. P. (2000). Effects of curing conditions on properties of concrete using slag replacement. Cement and Concrete Research, 30(3), 465-472.

Alexander, M. G., \& Magee, B. J. (1999). Durability performance of concrete containing condensed silica fume. Cement and concrete research, 29(6), 917-922.

Alonso, J.L., \& Wesche, K. (1992) Characterization of Fly Ash. Fly ash in concrete, properties and performance, RILEM Report, E \& FN Spon, 3-23.

ASTM C1202. (1994). Standard Test Method for Electrical Indication of Concrete's Ability to Resist Chloride Ion Penetration. Annual Book of ASTM Standards 4, 624-629. https://www.astm.org/search/fullsite-search.html?query=ASTM\%20C\%201202\&

ASTM C1585. (2004). Standard Test Method for Measurement of Rate of Absorption of Water by Hydraulic-Cement Concretes. American Society for Testing and Materials, West Conshohocken, PA. https://www.astm.org/search/fullsite-search.html?query=ASTM\%20C1585\&

ASTM C597-02. (2002). Standard Test Method for Pulse Velocity Through Concrete. Annual book of ASTM standards. Vol 04.02. Philadelphia. https://www.astm.org/DATABASE.CART/HISTORICAL/C597-02.htm

ASTM C666. (2008). Standard Test Method for Resistance of Concrete to Rapid Freezing and Thawing. Annual book of ASTM standards. https://www.astm.org/search/fullsite-search.html?query=ASTM\%20C666\&

Bilim, C., Atiş, C. D., Tanyildizi, H., \& Karahan, O. (2009). Predicting the compressive strength of ground granulated blast furnace slag concrete using artificial neural network. Advances in Engineering Software, 40(5), 334-340.

Cai, H., \& Liu, X. (1998). Freeze-thaw durability of concrete: ice formation process in pores. Cement and Concrete Research, 28(9), $1281-1287$.

Çakır, Ö., \& Aköz, F. (2008). Effect of curing conditions on the mortars with and without GGBFS. Construction and Building Materials, 22(3), 308-314.

Cao, C., Sun, W., \& Qin, H. (2000). The analysis on strength and fly ash effect of roller-compacted concrete with high volume fly ash. Cement and concrete research, 30(1), 71-75.

Celik, C., \& Burnak, N. (1998). A systematic approach to the solution of the design optimization problem. Total Quality Management, 9(1), 101-108.

Chan, Y. N., Luo, X., \& Sun, W. (2000). Compressive strength and pore structure of high-performance concrete after exposure to high temperature up to 800 C. Cement and Concrete Research, 30(2), 247-251.

Chung, C. W., Shon, C. S., \& Kim, Y. S. (2010). Chloride ion diffusivity of fly ash and silica fume concretes exposed to freeze-thaw cycles. Construction and Building Materials, 24(9), 1739-1745.

Davim, J. P. (2001). A note on the determination of optimal cutting conditions for surface finish obtained in turning using design of experiments. Journal of materials processing technology, 116(2-3), 305-308.

De Gutiérrez, R. M., Diaz, L. N., \& Delvasto, S. (2005). Effect of pozzolans on the performance of fiber-reinforced mortars. Cement and Concrete Composites, 27(5), 593-598.

Dhir, R. K., \& Jones, M. R. (1999). Development of chloride-resisting concrete using fly ash.Fuel, 78(2), 137-142.

Dinakar, P., Babu, K. G., \& Santhanam, M. (2008). Durability properties of high volume fly ash self compacting concretes. Cement and Concrete Composites, 30(10), 880-886.

Evangelista, L., \& De Brito, J. (2010). Durability performance of concrete made with fine recycled concrete aggregates. Cement and Concrete Composites, 32(1), 9-14.

Felekoglu, B. (2006). Utilisation of Turkish fly ashes in cost effective HVFA concrete production. Fuel, 85(12-13), 1944-1949.

Gokce, A., Nagataki, S., Saeki, T., \& Hisada, M. (2004). Freezing and thawing resistance of air-entrained concrete incorporating recycled coarse aggregate: The role of air content in demolished concrete. Cement and Concrete Research, 34(5), 799-806.

Hanžič, L., \& llić, R. (2003). Relationship between liquid sorptivity and capillarity in concrete. Cement and concrete Research, 33(9), $1385-1388$.

Hooton, R. D., \& Titherington, M. P. (2004). Chloride resistance of high-performance concretes subjected to accelerated curing. Cement and Concrete Research, 34(9), 1561-1567.

Jafari, K., Tabatabaeian, M., Joshaghani, A., \& Ozbakkaloglu, T. (2018). Optimizing the mixture design of polymer concrete: An experimental investigation. Construction and Building Materials, 167, 185-196.

Joseph, G., \& Ramamurthy, K. (2009). Influence of fly ash on strength and sorption characteristics of cold-bonded fly ash aggregate concrete. Construction and building materials, 23(5), 1862-1870.

Koulombi, N., Batis, G., Malami, C.H. (1993). Progress in the understanding and prevention of corrosion. In: Costa JM, Mercer AD (editor), The institute of materials, UK; p. 619.

Li, G., \& Zhao, X. (2003). Properties of concrete incorporating fly ash and ground granulated blast-furnace slag. Cement and Concrete Composites, 25(3), 293-299.

Liao, Y. S., Chu, Y. Y., \& Yan, M. T. (1997). Study of wire breaking process and monitoring of WEDM. International Journal of Machine Tools and Manufacture, 37(4), 555-567.

Lin, J. L., Wang, K. S., Yan, B. H., \& Tarng, Y. S. (2000). An investigation into improving worn electrode reliability in the electrical discharge machining process. The International Journal of Advanced Manufacturing Technology, 16(2), 113-119. 
Martys, N. S., \& Ferraris, C. F. (1997). Capillary transport in mortars and concrete. Cement and Concrete Research, 27(5), 747-760.

Mohammed, B. S., \& Fang, O. C. (2011). Mechanical and durability properties of concretes containing paper-mill residuals and fly ash. Construction and Building Materials, 25(2), 717-725.

Mohebi, R., Behfarnia, K., \& Shojaei, M. (2015). Abrasion resistance of alkali-activated slag concrete designed by Taguchi method. Construction and Building Materials, 98, 792-798.

Nian, C. Y., Yang, W. H., \& Tarng, Y. S. (1999). Optimization of turning operations with multiple performance characteristics. Journal of Materials Processing Technology, 95(1-3), 90-96.

Nochaiya, T., Wongkeo, W., \& Chaipanich, A. (2010). Utilization of fly ash with silica fume and properties of Portland cement-fly ash-silica fume concrete. Fuel, 89(3), 768-774.

Papadakis, V. G. (1999). Effect of fly ash on Portland cement systems: Part I. Low-calcium fly ash. Cement and Concrete Research, $29(11), 1727-1736$.

Ross, P.J. (1996). Taquchi Tecniques for Quality Engineering, 2nd ed., McGraw-Hill, New York. 102-113.

Sabir, B. B., \& Kouyiali, K. (1991). Freeze-thaw durability of air-entrained CSF concrete. Cement and Concrete Composites, 13(3), $203-208$.

Şahmaran, M., \& Li, V. C. (2009). Durability properties of micro-cracked ECC containing high volumes fly ash. Cement and Concrete Research, 39(11), 1033-1043.

Shang, H. S., Song, Y. P., \& Qin, L. K. (2008). Experimental study on strength and deformation of plain concrete under triaxial compression after freeze-thaw cycles. Building and Environment, 43(7), 1197-1204.

Shang, H., Song, Y., \& Ou, J. (2009). Behavior of air-entrained concrete after freeze-thaw cycles. Acta Mechanica Solida Sinica, 22(3), 261-266.

Shannag, M. J., \& Shaia, H. A. (2003). Sulfate resistance of high-performance concrete. Cement and Concrete Composites, 25(3), 363-369.

Siddique, R. (2011). Properties of self-compacting concrete containing class F fly ash. Materials \& Design, 32(3), $1501-1507$.

Siddique, R., \& Kadri, E. H. (2011). Effect of metakaolin and foundry sand on the near surface characteristics of concrete. Construction and building materials, 25(8), 3257-3266.

Siddique, R., Aggarwal, Y., Aggarwal, P., Kadri, E. H., \& Bennacer, R. (2011). Strength, durability, and micro-structural properties of concrete made with used-foundry sand (UFS). Construction and Building Materials, 25(4), 1916-1925.

Soroushia, P., Nagi, M., \& Okwuegbu, A. (1992). Freeze-thaw durability of lightweight carbon fiber reinforced cement composites. ACl Materials Journal, 89(5), 491-494.

Tanyildizi, H. (2013). Variance analysis of crack characteristics of structural lightweight concrete containing silica fume exposed to high temperature. Construction and Building Materials, 47, 1154-1159.

Tanyildizi, H. (2018). Long-term microstructure and mechanical properties of polymer-phosphazene concrete exposed to freeze-thaw. Construction and Building Materials, 187, 1121-1129.

Tanyildizi, H., \& Şahin, M. (2015). Application of Taguchi method for optimization of concrete strengthened with polymer after high temperature. Construction and Building materials, 79, 97-103.

Tanyildizi, H., Coskun, A., \& Somunkiran, I. (2008). An experimental investigation of bond and compressive strength of concrete with mineral admixtures at high temperatures. Arabian Journal for Science and Engineering, 33(2), 443.

Tanyildizi, H. (2014). Post-fire behavior of structural lightweight concrete designed by Taguchi method. Construction and Building Materials, 68, 565-571.

Türkmen, I.., Gül, R., \& Çelik, C. (2008). A Taguchi approach for investigation of some physical properties of concrete produced from mineral admixtures. Building and Environment, 43(6), 1127-1137.

Yahia, A., Tanimura, M., \& Shimoyama, Y. (2005). Rheological properties of highly flowable mortar containing limestone filler-effect of powder content and W/C ratio. Cement and Concrete Research, 35(3), 532-539.

Yazici, H. (2008). The effect of silica fume and high-volume Class C fly ash on mechanical properties, chloride penetration and freeze-thaw resistance of self-compacting concrete. Construction and Building Materials, 22(4), 456-462.

Yazici, H., Aydın, S., Yiğiter, H., \& Baradan, B. (2005). Effect of steam curing on class C high-volume fly ash concrete mixtures. Cement and Concrete Research, 35(6), 1122-1127.

Yiğiter, H., Yazici, H., \& Aydın, S. (2007). Effects of cement type, water/cement ratio and cement content on seawater resistance of concrete. Building and environment, 42(4), 1770-1776.

Yildirim, H., Ilica, T., \& Sengul, O. (2011). Effect of cement type on the resistance of concrete against chloride penetration. Construction and Building Materials, 25(3), 1282-1288.

Yüksel, İ., Bilir, T., \& Özkan, Ö. (2007). Durability of concrete incorporating non-ground blast furnace slag and bottom ash as fine aggregate. Building and Environment, 42(7), 2651-2659.

Yüksel, İ., Siddique, R., \& Özkan, Ö. (2011). Influence of high temperature on the properties of concretes made with industrial by-products as fine aggregate replacement. Construction and building materials, 25(2), 967-972. 